\title{
RISK FACTORS OF STUNTING IN CHILDREN AGED 2 to 5 YEARS AT OESAPA COMMUNITY HEALTH CENTER, KUPANG, EAST NUSA TENGGARA
}

\author{
Puspa M R Lay, Pius Weraman, Sabina Gero.
}

\author{
Masters Program of Public Health, Universitas Nusa Cendana
}

\begin{abstract}
Background: Stunting remains a global health problem. It refers to a health condition with impaired linear growth (height for age) in the early years of life. Stunting increases the risk of disturbance in growth and development even mortality during childhood. It can result in negative health effect across the lifespan, such as life-threatening complications during birthing, reduced cognitive performance, and development. This study aimed to determine the risk factors of stunting in children aged 2 to 5 years at Oesapa Community Health Center, Kupang, East Nusa Tenggara.

Subjects and Method: This was a case control study conducted at Oesapa Community Health Center Kupang, East Nusa Tenggara. A sample of 68 children aged 2 to 5 years was selected for this study, consisting of 34 stunted children in the case group and 34 children with normal height for age in the control group. The dependent variable was stunting. The independent variables were maternal knowledge, nutrition intake during pregnancy, parenting, and sanitation. The data of this study were obtained from the medical record and a set of questionnaire. The data were analyzed by a multiple logistic regression.
\end{abstract}

Results: The risk of stunting increased with low nutrition intake during pregnancy $(\mathrm{OR}=2.08 ; 95 \% \mathrm{CI}=1.75$ to 5.22$)$, low maternal knowledge $(\mathrm{OR}=1.98 ; 95 \% \mathrm{CI}=1.37$ to $4.36)$, poor parenting $(\mathrm{OR}=2.31 ; 95 \% \mathrm{CI}=1.66$ to 5.23$)$ and poor sanitation $(\mathrm{OR}=1.53$; $95 \% \mathrm{CI}=1.44$ to 6.21 ).

Conclusion: The risk of stunting increases with low nutrition intake during pregnancy, low maternal knowledge, poor parenting, and poor sanitation.

Keywords: stunting, children, nutrition intake, pregnancy, sanitation, maternal knowledge, parenting.

\section{Correspondence:}

Puspa M R Lay. Masters Program of Public Health, Universitas Nusa Cendana, Kupang 85001, East Nusa Tenggara, Indonesia. Email: puzpajeary@gmail.com. Mobile: o81339649327.

The $6^{\text {th }}$ International Conference on Public Health

Best Western Premier Hotel, Solo, Indonesia, October 23-24, 2019 | 233 https://doi.org/10.26911/the6thicph.03.91 